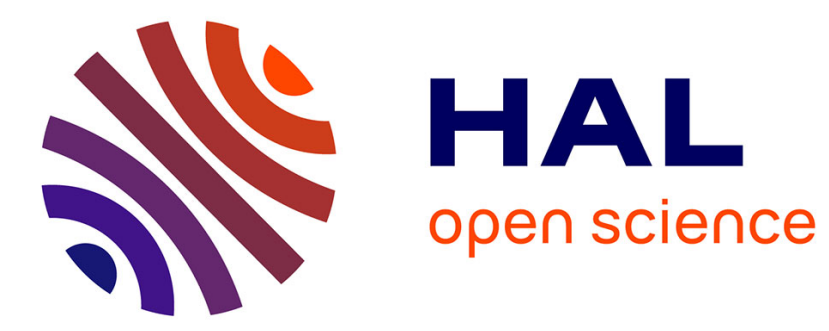

\title{
Headless Relative Clauses in Matlatzinca
}

Enrique L Palancar, Leonardo Carranza Martínez

\section{To cite this version:}

Enrique L Palancar, Leonardo Carranza Martínez. Headless Relative Clauses in Matlatzinca. Headless relative clauses in Mesoamerican Languages, pp.145-176, 2021. hal-03092489

\section{HAL Id: hal-03092489 \\ https://hal.science/hal-03092489}

Submitted on 2 Jan 2021

HAL is a multi-disciplinary open access archive for the deposit and dissemination of scientific research documents, whether they are published or not. The documents may come from teaching and research institutions in France or abroad, or from public or private research centers.
L'archive ouverte pluridisciplinaire HAL, est destinée au dépôt et à la diffusion de documents scientifiques de niveau recherche, publiés ou non, émanant des établissements d'enseignement et de recherche français ou étrangers, des laboratoires publics ou privés. 


\title{
Headless Relative Clauses in Matlatzinca
}

\author{
Enrique L. Palancar (SeDyL, CNRS) \\ Leonardo Carranza Martínez (UIEM)
}

\begin{abstract}
Chapter 5
Ivano Caponigro, Harold Torrence et Roberto Zavala (eds.). 2020. Headless relative clauses in Mesoamerican Languages, pp. 145-176. Oxford : Oxford University Press.
\end{abstract}

\section{Introduction and Basic Features of Matlatzinca}

In this chapter, we introduce the different headless relative clauses that exist in Matlatzinca. We show that headless relative clauses in Matlatzinca can be of different types, including free relative clauses. However, the most common type of headless relative clause is asyndetic; that is, it lacks both a complementizer and a relative pronoun. The next most common type is a light-headed relative clause headed by a pronominal demonstrative. In this chapter, we also show that maximal and existential free relative clauses are only built on wh-words such as 'who', 'what', and 'where'. These are basically the same $w h$-words that are naturally used in free-choice free relative clauses, although some speakers apparently also allow for the wh-word 'how much' in the latter. Finally, we show that headed relative clauses make use of most relativization strategies available for headless relative clauses, but not vice versa.

The chapter is organized as follows. In the remainder of this section, we introduce the basic features of Matlatzincan grammar that are relevant to the understanding of relative clause structure. In order to later discuss how productive or common free relative clauses are in this language compared to other types of relative clauses, we introduce $w h$-words in Matlatzinca in $\S 2$. In that section, we further show that most $w h$-words can also function as indefinite pronouns. $\S 3$ is dedicated to headed relative clauses, for which we find four different relativization strategies. $\$ 4$ introduces headless relative clauses. Free relative clauses are discussed in $\S 4.1$, while $\$ 4.2$ introduces other types of headless relative clauses. $\$ 5$ concludes.

Matlatzinca is an American Indian language from Mexico; it is spoken by about 1,000 people in the village of San Francisco Oxtotilpan in the State of Mexico (Lat.: 19.168889; Long.: -99.901944). Matlatzinca and Ocuiltec are the only surviving members of the Atzincan family, which, along with the Otomi-Mazahua group, form the Otomian branch of Oto-Pamean. Oto-Pamean, in turn, is seen as a branch of Oto-Manguean, the most diversified language family in the Americas. ${ }^{1}$

We base our analysis on natural language data from a collection of 7 hours and 30 minutes worth of spontaneous conversations and narratives in Matlatzinca, which were transcribed and translated into Spanish. The data were recorded and annotated under the auspices of the 20172019 ELDP-Major Documentation Project "Documentation of Matlatzinca: An Oto-Manguean language". We have retrieved many examples from this natural corpus, but we have also used elicited data in cases where certain structures are not attested in the corpus.

\footnotetext{
${ }^{1}$ The widely accepted view (discussed in Campbell, 2017) is that Oto-Pamean is a branch of Oto-Manguean, but Brown (2015) advances a powerful critique of the use of the historical method behind this conclusion and casts doubts about this affiliation that are far from inconsequential.
} 
To get a clearer idea of the syntax of relative clauses in Matlatzinca, it is important to know about at least three aspects of the grammar of the language, namely, constituent order, verbal inflection, and the basics of NP syntax. With respect to word order, Matlatzinca is a headmarking verb-initial language. ${ }^{2}$ In transitive clauses that have two overt NPs with equal degrees of animacy, the order is fixed to VOS in order to disambiguate which NP functions as the agent and which functions as the patient. This is shown in (1). While fronting of constituents is common in main clauses, in relative clauses it is not allowed, with the exception of pronouns in focus.
(1) tu
kwakí
[we
to_wa'a $]_{\text {овJ }}[$ we
to $\quad$ xuwí $]_{\mathrm{SUBJ}}{ }^{3,4}$
3.CPL hit
CLF.HUM boy(/child) CLF.HUM DIM girl
'The girl hit the boy.'/*'The boy hit the girl.'

As to verbal inflection, we note that all relative clauses in Matlatzinca have finite predicates. Matlatzinca verbs inflect for person/number of subject, TAM (Tense-Aspect-Mood), deixis, and voice; such inflections consist of clitic-like phonological words that always precede the verbal stem. ${ }^{5}$ Following Bartholomew (1966), we call such clitic-like words 'inflectional formatives'. ${ }^{6}$ For some subparadigms, contrasts in number and clusivity are instead encoded by suffixes. Table 1 gives four exemplary paradigms of the transitive verb táni 'buy'?

\footnotetext{
${ }^{2}$ Phonologically, Matlatzinca is a tone language with two level tones: low and high. Tone plays no role in the marking of verbal inflection; i.e., for our purposes, the predicate of a relative clause is in no way suprasegmentally different from the predicate of a main clause.

${ }^{3}$ Abbreviations not included in the Leipzig Glossing Rules convention: AMBU, ambulative; AS, adjusted stem; CPL, completive; DEP, dependent marking; DIM, diminutive; HES, hesitation; HUM, human; INAN, inanimate; INCPL, incompletive; INFL, inflectional class marker; LK, phonological linker; MANN, manner; MIDD, middle; NEG, negative; NMLZ, nominalizer; P, preposition; POT, potential; PRO, pronominal; PRTCL, discourse particle; Q, quantifier; SS, secondary stem; REASN, reason; TRANSLOC, translocative. An underscore (_) is used to segment morphs in words that have internal morphological structure that has become lexicalized.

${ }^{4}$ Orthography. Deviations from the IPA are as follows: ' $/ \mathrm{P} / ; \mathrm{ch} / \mathrm{t} / ; \mathrm{chh} / \mathrm{t}{ }^{\mathrm{h}} / ; \ddot{\mathrm{e}} / \mathrm{s} / ; \mathrm{i} / \mathrm{i} / ; \mathrm{kh} / \mathrm{k}^{\mathrm{h}} / ; \mathrm{mh} / \mathrm{m}^{\mathrm{h}} /[\mathrm{m}] ; \mathrm{nh}^{\mathrm{h}} / \mathrm{n}^{\mathrm{h}} /$ $[\mathrm{n}] ;$ th $/ \mathrm{t}^{\mathrm{h}} / ; \mathrm{x} / \mathrm{J} /$; and $\mathrm{y} / \mathrm{j} /$. Low tone is left unmarked and high tone is marked with an acute accent over a vowel

${ }^{5}$ In previous works on Matlatzinca (except for Bartholomew, 1966), inflectional formatives, nominal classifiers, and number determiners have been treated as prefixes (Soustelle, 1937; Cazes, 1971; Escalante \& Hernández, 1999; Pascacio Montijo, 2006, 2017; Pérez, 2010; Carranza Martínez, 2012; and Gómez González, 2015). In the light of natural data, we consider the analysis of such elements as affixes to be wrong. Natural prosody reveals that all such elements can (and often do) occur before hesitation pauses. In hesitation, the elements can be (and often are) repeated and are sometimes corrected by speakers in subsequent discourse. Such behaviour goes against the quintessential nature of affixes.

${ }^{6}$ Monosyllabic formatives are often unstressed and behave like simple clitics. Their host may not be the verbal stem but the preceding word. Because of their fluctuating prosody, we have chosen to represent them as phonological words.

${ }^{7}$ Some inflectional formatives have internal structure pointing to agglutinative composition. However, in none of the cases where segmentation is possible (indicated with an underscore) is there a systematic one-to-one mapping between smaller units and possible function. This suggests that these days, the combinations function as singletons.
} 


\begin{tabular}{|c|c|c|c|c|}
\hline & \multicolumn{2}{|c|}{ CPL } & \multicolumn{2}{|c|}{ INCPL } \\
\hline & Realis & Irrealis & Realis & Irrealis \\
\hline $1 \mathrm{SG}$ & to' táni & rú táni & tuh táni & rúh táni \\
\hline $2 \mathrm{SG}$ & 'o táni & ri táni & 'íh táni & ri 'íh táni \\
\hline $3 \mathrm{SG}$ & tu táni & tá' tu táni & kuh táni & táh táni \\
\hline 1DU.INCL & ko' táni & rú tán-wewí & kwen táni & rú_kwen táni \\
\hline 1DU.EXCL & ko’bú táni & rú tán-we[wí]-bí & kwén táni & rú_kwén táni \\
\hline 2DU & cho’ táni & ri tán-wewí & chen táni & ri_chen táni \\
\hline $3 \mathrm{DU}$ & tu tán-wewí & tá' tu tán-wewí & kwén táni & tá'_kwén táni \\
\hline 1PL.INCL & kho’ táni & rú tán-hë & khwen táni & rú_khwen táni \\
\hline 1PL.EXCL & kho’bú táni & rú tán-hë-bí & khwén táni & rú_khwén táni \\
\hline $2 \mathrm{PL}$ & chho’ táni & ri tán-hë & chhen táni & ri_chhen táni \\
\hline 3PL & tu tán-hë & tá' tu tán-hë & ron táni & tá'_ron táni \\
\hline
\end{tabular}

Table 1. Four exemplary subparadigms of the verb táni (tr) 'buy'

The reader should be made aware that inflectional formatives display allomorphy; some verbs in the examples below occur with formatives other than the ones in Table 1 (for more details, see Palancar and Carranza Martínez 2017). In the verbal complex, a set of adverbial elements may occur between the inflectional formative and the stem to indicate notions of deixis, locative relations, and manner. Two examples are given in (2). ${ }^{8}$

(2) a. ma ku nás yë ne xuni ro’ sé'ki

Q 3SG.INCPL BELOW be.there PL agave 3PL.CPL blossom

'There are many agave below there that have blossomed.' (rn_pulque_ 287)

b. chhen tu khana 'eni?

2PL.INCPL INFL WELL play

'Did you use to play well?' (an_juegos_091.b)

We now discuss some basics of NP structure that are relevant to understanding relative clauses in Matlatzinca. Some relative clauses in Matlatzinca may be introduced by elements which also occur in NPs, so it is convenient to introduce these elements here. Nouns rarely occur bare; when they do, they function as incorporated nouns, as shown in (3). Apart from a handful of human nouns that co-occur with the human classifier we, like the noun towa' $a$ 'boy/child' in (4a), ${ }^{9}$ and the handful of nouns that co-occur with the classifier $n i$, like ' $x i$ 'onion' in (4b), ${ }^{10}$ all nouns cooccur with the general classifier $n,{ }^{11}$ be they human (proper or common) or not, like in (5).

\footnotetext{
${ }^{8}$ Note that an example like (2b) is an instance of a Matlatzinca verbal complex, which is very similar to verbal complexes in French, such as shown in (i):
(i) je $\quad n$ 'y ai jamais pensé
1SG NEG-LOC 1SG.PRS.IND.have never think.PST.PRTCP

'I never thought about it.'

${ }^{9}$ Speakers may use the human classifier we with nouns that do not commonly bear it. E.g. (5a) also occurs as we be 'xóki 'bell ringer' (an_mole_048).

${ }^{10}$ Bartholomew (1966:46) points out that the classifier $n i$ occurs in a handful of nouns, including old deverbatives (e.g. ni_khwechi 'broom' from khwechi 'sweep'), some nouns denoting atmospheric events (e.g. ni_nhechi 'ray'), and a miscellanea of other nouns. While older speakers still treat $n i$ distributionally as a classifier, younger speakers have reanalyzed it as part of the phonology of the stem.

${ }^{11}$ There is also the allomorph in, selected when the nominal stem has an onset in /r/ as in in ruthani 'bird'.
} 
(3) 'ix pe ri'i na+khwa and already 2SG.INCPL.IRR want.AS+rabbit

'And if you want rabbit.' (ar_animales_189)

(4) a. man té huti pëkhi we to_wa'a pero... 3SG.AMBU MIDD walk here CLF.HUM (boy/)child but 'The child was walking around here, but...' (ar_presentacion_32)

b. aha... mu 'íh yëh-pi ni_xi? aha also 2SG.INCPL put.AS-APPL.BEN[3OBJ] [CLF+]onion

'Aha! Do you also add onion to it?' (lu_mole 068.b)

(5) a. luego ni t'ëti n be'_xóki... then 3POSS sack CLF bell.ringer

'then the bell ringer's sack...' (ar_ofrenda_449)

b. chhi n Carlos?

and CLF C.

'And Carlos?' (fe_lengua_418)

c. ah!, ni n tëni?

ah! DEM CLF flower

'Ah, this flower?' (rn_pulque_293.b)

We take nominal classifiers in Matlatzinca to be functional elements that license a noun in an NP. Classifiers are dropped when the noun is possessed or when it is determined by number. ${ }^{12}$ Examples are given in (6), with the nouns towa'a 'boy/child' (CLF we), 'xi 'onion' (CLF ni_) and becerra 'calf' (CLF $n)$.

(6) a. ka ron huxna ne to_wa'a

PRTCL 3PL.INCPL get.stung.by.chili PL (boy/)child

'The children became overwhelmed by eating chili.' (te_enfermo_205)

b. te $x i$

DU onion

'the/some two onions'

c. $\mathrm{pe}=\mathrm{n}$ ga to'... to(') 'u-wewí te... te becerra already=LK PRTCL 1SG.CPL 1SG.CPL sell.AS[3OBJ]-DU[OBJ] DU DU calf 'And I sold the two calves.' (cl_hongos 117)

In §3.2.3 and §4.2.2. we will see that there are two relative clause types that involve the general classifier. Although Escalante and Hernández (1999) treat the general classifier as a definite article, in reality neither classifiers nor number determiners carry inherent definiteness; ${ }^{12}$ This distribution takes Gómez (2015) to equate Matlatzinca classifiers with the so-called 'absolutive' markers in
Nahuatl with which they bear typological resemblance. 
definiteness is, rather, inferred from the context. ${ }^{13}$ For example, while the NP in (7a), which has a countable noun, behaves like a definite description and is referential, the one in $(7 \mathrm{~b})$, which has a mass noun, behaves like an indefinite (a similar case is argued in Gómez, 2015). ${ }^{14}$

(7) a. t'i ron ná kïwi n campana...

DEM 3PL.INCL down pull CLF bell

'those that pull down the bell...' (an_mole_044)

b. puro $\mathbf{n}$ to sa

only CLF DIM wood

'just wood' (an_juegos_028)

When speakers do not want to leave definiteness interpretations up to the context, they can use other means to encode such notions: an indefinite determiner to signal indefiniteness, as in (8), or a demonstrative to signal definiteness, as in $(9 a, b)$. The examples in (9) illustrate the distal demonstrative $t$ ' $i$. Demonstratives are very rarely sensitive to number when used as determiners.

ka... khwé' kïki na $\mathbf{n}$ to piní 'ix...

PRTCL 1PL.EXCL.INCPL take INDF CLF DIM pot and

'And we take a pot and...' (an_mole 012)

(9) a. $\mathrm{ku}$ 'ini t'i $\mathrm{n}$ to t'uxuhmu

3SG.INCPL say DEM CLF DIM woman

'That/the woman says.' (cl_hongos_087)

b. cha' me t'i ne khëchhë ne mexa

NEG be.there DEM PL year PL table

'In those years, there were no tables.' (ma_ofrenda_083)

Demonstratives can be used pronominally, as in (10). This will be important for our analysis of a light-headed relative clause which has a demonstrative as its head (\$4.2.1).

(10) a. mhëxi tu 'in khëchhë t'i?

how.many 3.CPL reach(time) year DEM $_{\mathrm{PRO}}$

'How old is that?' (Lit. 'How many has it reached (in) years?') (te_vida_120.b)

b. t'ët'i ga tu si

DEM $_{\text {PRO }}$ COP 1SG.INCPL ingest

'That is what I used to eat.' (fe_vida1 107)

\footnotetext{
${ }^{13}$ NPs with number determiners are also unspecified for definiteness, as shown in (i):

(i) ron tu nëhchi te nowi te colote

3PL.INCL INFL lift DU two DU big.basket

'They used to (be able to) lift two big baskets.' (pa_vida_197)

14 The utterance in (7b) was produced when the speaker was recounting old techniques used by children to build spinning tops. The context was: 'Then (the other kids) would say (to us): "just wood"'. The utterance 'just wood' is the verbal report given by children that the ultimate trend in spinning tops only involved tops built of wood.
} 
The demonstrative system is of the proximal-distal type. The forms appear in Table 2. Demonstratives lack a dual form (the singular invariable form can be used if necessary) and the plural forms in Table 2 are practically only ever used pronominally. There are two alternative forms for proximal and distal demonstratives, which contrast in specificity-roughly, 'that one' vs. 'that very one'. Forms such as $n i+n h i$ and $t i+t$ ' $i$ are more specific than $t$ ' $\ddot{e}+n h i$ and $t$ ' $\ddot{e}+t$ ' $i$.

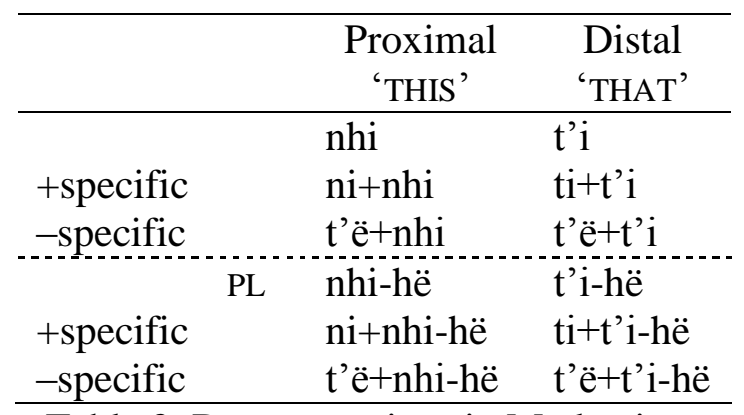

Table 2. Demonstratives in Matlatzinca

The use of demonstratives as pronouns in (10) leads us naturally toward the presentation of the other pro-forms given in Table 3 .

\begin{tabular}{|c|c|c|c|c|}
\hline & SG & & DU & PL \\
\hline \multirow[t]{2}{*}{$1^{\mathrm{st}}$} & kakí/gakí & EXCL & kakwebi/gakwebi & kakhëwi/gakhëwi \\
\hline & & INCL & kakwéwi/gakwéwi & kakhówi/gakhówi \\
\hline $2^{\text {nd }}$ & kach'i/gach'i & & kahch'éwi/gahch'éwi & kahch'ówi/gahch'ówi \\
\hline $3^{\text {rd }}$ & ret'ëwi & & ret'ëwewí & ret'ëhë \\
\hline
\end{tabular}

Table 3. Personal pronouns in Matlatzinca

In Table 3, we can see that forms for the first and second persons involve the formative element $\mathrm{ka} / \mathrm{ga}^{15}$ For the third person, apart from the pronominal use of demonstratives, the language has two other pro-forms: the form $r e(n)$ is invariable; but the form ret'ëwi-based on a combination of $r e$ and $t$ ' $\ddot{e}$ plus the stem formative $+w i$-inflects for all number values.

\section{Wh- Interrogative Clauses in Matlatzinca}

The $w h$-words found in Matlatzinca are given in Table 4, where we have ordered them according to their English equivalents. In $\$ 2.2$ we show that some of these words can also be used as indefinite pronouns.

${ }^{15}$ The element $\mathrm{ka} / \mathrm{ga}$ is homophonous with one of the two copulas. This suggests that pro-forms for speech act participants emerged from the lexicalization of truncated clefts of the type 'It's me'. 


\begin{tabular}{|c|c|c|}
\hline \multirow[t]{3}{*}{ WHO } & & want'ë(wi) \\
\hline & WHO-DU & want'ë-wewí \\
\hline & WHO-PL & want'ë-hë \\
\hline WHAT & & nt'ani \\
\hline \multirow[t]{2}{*}{ WHICH/WHAT } & WHICH & yant’ë(wi) \\
\hline & $\mathrm{WHAT}+\mathrm{N}$ & nt'ani + mu N \\
\hline \multirow{3}{*}{$\begin{array}{l}\text { WHEN } \\
\text { WHERE }\end{array}$} & & yahkhá \\
\hline & & poht'i \\
\hline & & $\begin{array}{l}\mathrm{poh}+\mathrm{pu} \\
\mathrm{pu}\end{array}$ \\
\hline HOW/WHY & & pu... + khá V \\
\hline WHY & & 'in_khá \\
\hline HOW MUCH/MANY & & mhëxi $(+N)$ \\
\hline
\end{tabular}

Table 4. List of wh-expressions in Matlatzinca

Wh-words must occur clause-initially in interrogative clauses, as shown in (11a,b) for yahkhá 'where' and mhëxi 'how much'.

(11) a. yahkhá 'o té huti
WHEN 2SG.CPL MIDD arrive
'When did you arrive?'

b. xi mhëxi 'a pánta tit'i

and HOW.MUCH 2SG.TRANSLOC sell DEM PRO

'And for how much did you use to sell them?' (cl_vida 181.b)

The language does not allow for multiple $w h$ - interrogative clauses, as shown by the impossibility of the co-occurrence of 'who' and 'what' in (12a). Example (12b) cannot be interpreted as a multiple- $w h$ - interrogative clause, but only as single- $w h$-interrogative clause with the right-most $w h$-word behaving like an indefinite.

(12) a. *want'ëwi nt'ani tu 'ini?

WHO WHAT 3.CPL say

'['Who said what?']

b. want'ëwi tu 'ini nt'ani?

WHO 3.CPL say WHAT

'Who said something?'/*'Who said what?'

Wh-words in argument position are not marked for case. For example, want'ëwi 'who' in (13a) indicates a question about the subject, while in (13b) the same form indicates a question about the object. 
(13) a. want'ëwi táh p=habi-ki o?, ren?

WHO 3SG.INCPL.IRR THERE=leave-1OBJ PRTCL $3_{\text {PRO }}$

'Who is going to leave me there, eh? Or what?' (fe_vida1_229)

b. want'ëwi 'o hiht-hë?

WHO 2SG.CPL teach.AS[3OBJ]-PL[OBJ]

'Who (PL) did you teach? (an_ofrenda.le_10)

In the same way, number is not marked on the wh-word for 'who' when it is used as an interrogative in first position in the clause. Note for example that in (13b), where the object is plural, the form remains invariant. ${ }^{16}$ In contrast, the $w h$-word is marked for number when it is used as a predicate, as in (14), or when it is used as a pronoun in a free relative clause (see also (41b) in $\$ 4.1 .1$ for an example with the dual). Additionally, example (14) illustrates that the element $w i$ in the form want'ëwi is a stem formative that is dropped when the base receives suffixation, or when the wh-word procliticizes to a following word, as in (15); this process is very common in discourse.

(14) pero n+yë, want'ë-hë?

but HES.FILLER WHO.AS-PL

'But eh... who were they?' (ra_campanas_016)

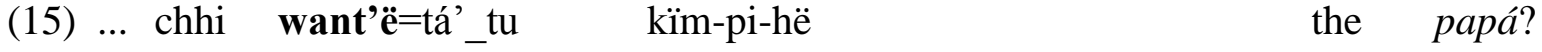
but WHO.AS=3SG.CPL.IRR grind.corn.AS-APPL.BEN[3OBJ]-PL[OBJ] 1POSS parent
'But who will grind corn for my parents?' (te_vida2_437)

The $w h$-word for 'what' is $n t$ 'ani, seen in (16); and the $w h$-word for 'which' is yant'ëwi, seen in (17). However, as an interrogative $w h$-word yant'ëwi can only be used pronominally; that is, it cannot combine with an N. As shown in (18), in order to ask about the type of object pertaining to a certain class, one must use $n t^{\prime} a n i$ 'what' plus a noun preceded by an indefinite marker meaning 'other'.
nt'ani 'íh yëh-pi?
WHAT 2SG.INCPL put.in-APPL.BEN[3OBJ]

'What do you put in it?' (lu_mole 043.b)

(17) yant'ëwi 'íh thï'ì?

WHICH 2SG.INCPL bring

'Which one are you bringing?'

(18) pero nt'ani mu be mëni chhan tu hëwi o? nt'ani?

but WHAT other NMLZtalk 2PL.AMBU INFL do PRTCL WHAT

'But what sort of chat were you (PL) (going around) having, eh? Or what?' (ra_presentación 21)

\footnotetext{
${ }^{16}$ The plural suffix -hë cross-references the plural subject for this particular TAM subparadigm.
} 
There are various ways of questioning with respect to location. Speakers may use the wh-word $p o h+t$ ' $i$ 'where', as in (19a), consisting of the wh-word poh-plus the demonstrative $t^{\prime} i$. Alternatively, they may use a cleft structure as in (19b), where $p o h+t$ ' $i$ is used as a predicate and the relative clause of the cleft (indicated by the square brackets) is introduced by the wh-word $p u$, where it functions as a relative pronoun. We propose that the cleft in (19b) gave rise to the $w h$-word $p o h+p u$ in $(19 \mathrm{c})$, and that in turn gave rise to the use of $p u$ as a $w h$-word, as in (19d).
a. ta Armando, $\mathbf{p o h}+\mathbf{t}$ 'i $\mathbf{i}$ 'i nïta?
Mr. A.
WHERE+DEM 2SG.INCPL be.born
'Mr. Armando, where were you born?' (ar_vida_01)
b. poh+t'i [pu 'é $\quad$ mhiri]?
WHERE+DEM WHERE 2SG.CPL.MIDD hire
'Where is it that you offered your services as a worker?'
(Lit. 'Where is it where you hired yourself?') (fe_vida1_015)
c. poh+pu man té huti $\mathrm{n}$ chu?
WHERE+WHERE 3SG.AMBU INFL walk CLF uncle
'Whereabouts is uncle? (cl_vida_311.b)
d. pu 'an té huti rhanta ka rhi_xeni?
WHERE 2SG.AMBU MIDD walk day.before.yesterday 3SG.CPL be.night
'Where were you (walking about) the day before yesterday at night?' (ar_presentacion_13)

Questioning with respect to manner or reason also involves the $w h$-word $p u$ 'where', as seen in (20), but in these cases there is usually a need for the manner/reason adverbial khá in the verbal complex, as in (20a). A common exception is (20b), which is a fixed expression that involves the homophonous existential verb $k h a{ }^{17}$ Other constructions used for questioning with respect to manner or reason use the adverbial khá but do not involve a $w h$-word; these look like polar questions. Examples are given in (21). Example (21a) has two clefts where the general pronoun for third person serves as the focus phrase that is the target of the questioning. ${ }^{18}$

a. pu chen tu khá hëwi?

WHERE/HOW 2PL.INCPL INFL MANN/REASN do

'How do you do it?' (ar_ofrenda 147 turned into a question)

b. pu ' ' $\mathrm{i}$ kha Don Rafa?

WHERE/HOW 2SG.INCPL live/exist Mr. R.

'How are you doing, Mr. Raphael?' (ra_presentación_01)

\footnotetext{
${ }^{17}$ The expression originated from an interrogative clause with the adverbial $k h a$, but due to the high frequency of use of the expression, the adverbial was dropped to avoid the repetition in the sequence [khakha].

${ }^{18}$ The formative $m u$, glossed as 'dependent' (DEP), is used for $\{3$ SG.INCPL $\}$ in negative, interrogative, and relative clauses (Bartholomew, 1966, p. 22).
} 
(21) a. ren rú khá 'ini?, ren rú khá tó'ts'i? $3_{\text {PRO }}$ 1SG.CPL.IRR MANN/REASN say $3_{\text {PRO }}$ 1SG.CPL.IRR MANN/REASN answer 'How am I going to talk? How I am going to answer?' (fe_lengua_045)

(Lit. 'Is it that I'm going to talk in a way? Is it that I'm going to answer in a way?')

b. ni' ch'ahmu, mu khá ts'opi?

2SG.POSS man 3SG.INCPL.DEP MANN/REASN be.called

'And your husband, what is his name?' (Lit. '...he's how called?') (cl_vida_070)

(Lit. 'And your husband, he is in a way called?')

\subsection{Embedded Wh- Interrogative Clauses}

An interrogative clause introduced by a $w h$-word can be embedded as a clausal complement of a matrix verb. This is illustrated in (22) with various types of $w h$-words. In each case the interrogative clause is indicated with square brackets.

(22) a. cha' tu tu khana pëyá [poh+pu ré pënti meryu]

NEG 1SG.INCPL INFL WELL know WHERE+WHERE 3SG.CPL.MIDD find money

'I don't know well where he found the money.' (dinero_011)

b. xa' ' $\mathrm{i}=\mathrm{m}$ pëyá $[\mathbf{p u}$ ri 'akhá] $o$ [nt'ani ri_cho'=ré tëti]

NEG 2SG.INCPL=INFL know WHERE 2SG.CPL.IRR go or WHAT 2DU.FUT=MIDD find 'You don't know where you're going to go or what you'll find.' (au_cueva_116)

c. ni tuh pëti [want' $\ddot{e}=t$ 'i we be' t'ani]

nor 1SG.INCPL know who=DEM CLF.HUM worker

'And I don't even know who that worker is.' (te_vida1_085)

Embedding can involve a whole clause or just the wh-word as a predicate, as in (23) or in the conversational exchange in (24).

(23) ret'ë-hë ron pëyá [poh+pu]

$3_{\text {PRO-PL }}$ 3PL.INCPL knOW WHERE+WHERE

'They know where it is.' (cl_hongos_008.b)

(24) a. —xa' yahkhá 'o pëyá [want'ëwi]?

NEG WHEN 2SG.CPL know WHO

'You never knew who it was?' (ma_mole_188)

b. —cha' yahkhá to' pëyá [want'ëwi]

NEG WHEN 1SG.CPL know WHO

'I never knew who it was?' (ma_mole_189) 
Interrogative clauses of manner or reason that do not involve a $w h$-word can also be embedded. This is shown in (25). Here the matrix predicate is a loanword from Spanish.

\begin{tabular}{|c|c|c|c|}
\hline (25) quien_sabe & {$[\mathrm{mu}$} & khá & kha] 'o \\
\hline who.knows & 3SG.INCPL.DEP & MANN/REASN & live/exist PRTCL \\
\hline
\end{tabular}

\subsection{Wh-words as Indefinite Pronouns}

In Matlatzinca, the subset of $w h$-words given in Table 5 can also serve as indefinite pronouns in statements where they occupy argument position, or in adverbial phrases.

\begin{tabular}{|c|c|c|c|}
\hline \multirow[t]{3}{*}{ WHO } & & want’ë(wi) & 'someone' \\
\hline & WHO-DU & want'ë-wewí & 'someone.DU' \\
\hline & WHO-PL & want’ë-hë & 'someone.PL' \\
\hline WHAT & & nt'ani & 'something' \\
\hline WHEN & & $(\mathrm{pu}+)$ yahkhá & 'sometimes' \\
\hline WHERE & & poht'i & 'somewhere' \\
\hline
\end{tabular}

Table 5. List of wh-words in Matlatzinca working as indefinite pronouns

We saw an example of this with yahkhá 'when' in (24) above. (26) illustrates the same observation for want'ëwi 'who'. The wh-word nt'ani 'what' shows a wider scope of use as an indefinite: in (27a) it functions as an indefinite pronoun, and in (27b) as an indefinite determiner. The wh-word $n t$ 'ani is a result of the co-lexicalization of the indefinite noun translatable as 'thing' plus the general classifier. An example is (28).

(26) a. osea ki tu tirí want'ëwi, pero gakí cha' yoko that.is that 3.CPL scare[3OBJ] WHO but $1 \mathrm{SG}_{\mathrm{PRO}}$ NEG never 'That's to say that someone scared them, but as for me, never.' (au_cueva_063)

b. ki... gi (tu) hé want'ëwi xi' muh t-hé PRTCL PRTCL 3.CPL see WHO NEG 3SG.INCPL.DEP INFL-see[3OBJ]

'And he made sure that nobody would see him.' (au_olla_061)

(27) a. tá'ré hëhya nt'ani

3SG.CPL.IRR.MIDD need WHAT

'(Be it the case that) something may be needed.' (ar_animales_266.b)

b. me nt'ani mu $\mathrm{n}$ to fruta rú so'ts'í... or WHAT other CLF DIM fruit 1.CPL.IRR put

'Or I may put any other fruit in it...' (an_ofrenda_046)

(28) mëchi na $\mathbf{n}$ t'ani [khwen t'ini...]

pierce.IMP INDF.SG CLF thing 1PL.INCL.INCPL SS.say

'Pierce the thing that we call...' (fe_lengua_148) 
The indefinite noun in this last example also serves as the head of the relative clause, as indicated by the square brackets, but note that the relative clause is not introduced by any element. This corresponds to a specific type of relative clause in Matlatzinca that we call the 'asyndetic' type. This discussion leads us naturally into the next section, where we introduce headed relative clauses, including the asyndetic type just mentioned.

\section{Headed Relative Clauses in Matlatzinca}

In this section, we introduce the different types of headed relative clauses that are found in Matlatzinca. All relative clauses in Matlatzinca, regardless of type and function, are finite, postnominal, and include a gap (in the sense used in Caponigro, this volume). Headed relatives in this language are always externally headed. As we show in the next subsection, there is only one type of headed relative clause that is introduced by a $w h$-word: the locative type.

\subsection{Headed Relative Clauses with a $W h$-word}

When the head of the relative clause has a locative function inside the relative clause, the relative clause is introduced by the $w h$-word $p u$ 'where', as shown in $(29 \mathrm{a}, \mathrm{b})$. The head of each relative clause is underlined for convenience. In (29a) the head is a noun, whereas in (29b) it's an adverbial.
a. ne caja [pu ron t'i $\quad \mathrm{n}$ táthuwi]
PL box WHERE 3PL.INCPL keep.grain SG maize
'The boxes where they used to keep the maize.' (lumbre_239)
b. kah xá'ti $\mathrm{n}$ ch'ahmu kharu $[\mathbf{p u = n}$ yë ne xi'pe'e] 3SG.CPL fall SGman there WHERE=LK be.located PL bramble
'The man fell down there where the brambles are.' (ar_historias_121)

When discussing the different $w h$-words for 'where' in $\S 2$, we pointed out that the original function of $p u$ appears to have been that of a locative relative clause pronoun. Indeed, the whword originated lexically from the adverbial $p u$ 'there' given in (30), an example where the adverbial receives further modification by a relative clause.

(30) $\mathbf{p u} \quad[\mathbf{p u}$ ron chobi grava, t'i te'so $\mathrm{n}$ tó $]$ there WHERE 3PL.INCPL place gravel DEM all SG stone

'Over there where they put the gravel (and) all the stone(s).' (fe_aserradero_012)

\subsection{Headed Relative Clauses Not Involving a $W h$-word}

\subsubsection{The Asyndetic Type}

The most common headed relative clause in Matlatzinca is one that has neither a complementizer nor a relative pronoun. We call this type of relative clause 'asyndetic'. Examples are given in (31) below. (31a) and (31b) illustrate cases with relativized subjects, which are human and inanimate, respectively. (31c) has two relative clauses, the first of which has a relativized object. The example in (31d) shows a case of a relativized instrument. 
(31) a. bueno ne to gente [pëkhi khwén chhori fot'u maani — subs] well PL DIM people here 1PL.EXCL.INCPL live our.ADV AS.home ta gi rú_khwé' kabí $\mathrm{n}$ to meryu...

if COP 1PL.EXCL.INCPL.IRR possess CLF DIM money

'Well, the people who (we) are here at our village, if it were (the case) that we had money...' (ra_campanas_085.b-087.b)

b. kho'bu hé na $\mathrm{n}$ to mu'u [kuh ts'irí —subs] 1PL.EXCL.CPL see one CLF DIM gourd 3SG.INCPL hang

'We saw a gourd which was hanging.' (ar_historias_023)

c. t'ë ninhi 'ox t'i n maa-boyi [ko'bu 'uri__oв],

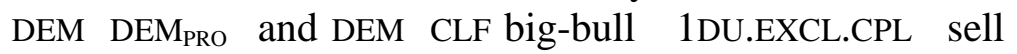
[cha' mu té hechí _suBs] NEG 3SG.INCPL.DEP MIDD grab

'This one and that big bull that we sold, which didn't let itself be grabbed.' (cl_hongos_160)

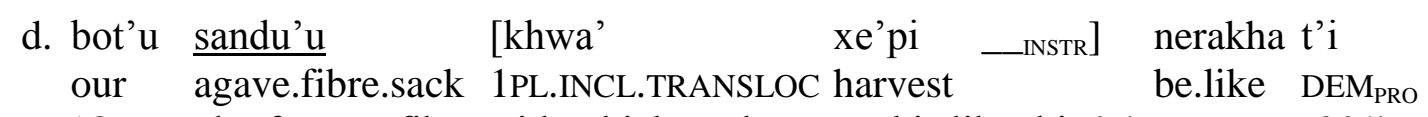

'Our sack of agave fibre with which we harvested is like this.' (an_ayates_301)

\subsubsection{The Complementizer Type}

There is another type of headed relative clause that is introduced by the overt complementizer $k i$. Examples of non-restricted uses are given in $(32 a, b) .(33)$ is an appositional relative clause. Example (34) illustrates that $k i$ is a complementizer that can introduce other types of subordinate clauses, like complement clauses.
a. ... ron
té xini ninhi ne to $\underline{\text { ch'ahmu }}$
[ki ron
nawí
... 3PL.INCPL MIDD talk DEM PL DIM man COMP3PL.INCPL want
'...These men who want us to... are talking.' (ra_presentación_53)
b. para ne to ch'a to ts'omhewi [ki ron yë —ов gakharu] P:with PL DIM little DIM bread COMP 3PL.INCPL make in.the.past

'With the small loaves of bread that they used to make in the past.' (ar_ofrenda_555.b)

(33) we tú the chu Obispo, $[\mathbf{k i}$ ron t'ini $\mathrm{n}$ Pozole $]$

CLF.HUM dead 1POSS uncle Obispo COMP 3PL.INCPLSS.say CLF P.

'My late uncle Obispo, the one who they called "Pozole".' (fe_lengua_356-357)

(34) $\mathrm{ku}$ 'ini [ki tá' ho' hechí]

3SG.INCPL say COMP 3.FUT leave

'They used to say that he should stop (drinking).' (rn_pulque_042) 


\subsubsection{The Relativizer Type}

There is yet a third type of relative clause construction, one that involves a relative clause introduced by the relativizer $n$. We define a relativizer as a complementizer that is specifically used to introduce a relative clause. An example of such a clause with a relativized instrument is given in the response to the question in (35). This type of relative clause is the preferred choice when the head is a pronoun, as in (36). It is also used appositionally, as in (37), which also shows an instance of pied-piping with a preposition borrowed from Spanish.

$\begin{array}{rllll}\text {-n kuchiru } & \text { 'a } & \text { përi } & \text { o } & \text { nt'ani? } \\ \text { CLF machete } & \text { 2SG.TRANSLOC } & \text { hit[3OBJ] } & \text { or } & \text { WHAT }\end{array}$

-'Did you hit it (the snake) with a machete or (with) what?' (fl_plantas_058.b)

-na $\mathrm{n}$ sa, na $\mathrm{n}$ sa $\left[\begin{array}{llllll}n & \text { tan } & \text { për-hë ne } & \text { vaca } & \text { —instr }\end{array}\right]$ one CLF stick one CLF stick REL 1SG.AMBU hit-PL PL cow

-'With a stick, with a stick with which I hit the cows.' (fl_plantas_060)

(36) want'ëwi $\left[\begin{array}{llllllll}n & \text { ga } & \mathrm{n} & \text { loco }\end{array}\right.$ ga tu someone REL COP CLF madman COP 3SG.CPL throw one CLF gourd 'Someone who was a madman was (the one who) threw a gourd.' (ar_historias_113)

(37) ah pi' nana Santa [para $\mathbf{n}$ khwen t'ini $\mathrm{n}$ cuate $]$

! P.LOC Mrs. S. P:to REL 1PL.INCL.INCPL SS.Say CLF buddy

'Ah! At Mrs. Santa's, whom we call "The Buddy”.' (te_vida2_401)

The element $n$ in examples like (35)-(37) derives from the general classifier $n$, but we treat it as a relativizer because this relative clause is not sensitive to either the number features or the classifier features of the head nominal. For example, in (38a), with a plural head noun, the construction still requires $n$ and not a matching number determiner; and in (38b), there is no matching at classifier level.

(38) a. mu niht-hë ne familia [*ne/n khwén té so'pi]... other DEM-PL PL family PL/REL 1PL.EXCL MIDD talk 'these other families with whom we used to speak...' (ma_ofrenda_649-650)

b. t'i we to wa'a [*we/n to' hé] DEM CLF.HUM (boy/)child CLF.HUM/REL 1SG.CPL see 'those children that I saw'

Having introduced the main types of headed relative clauses that we find in Maltatzinca, in the next section we discuss headless relative clauses. We will see in $\S 4.2 .1$ that certain instances of two subtypes of headless relative clauses, namely, the light-headed type and the classifier type, could be analyzed as headed structures. 


\section{Headless Relative Clauses in Matlatzinca}

Matlatzinca has a rich array of headless relative clauses: the familiar three kinds of free relative clauses, which we discuss in $\S 4.1$, and five other types that we discuss in $\S 4.2$.

\subsection{Free Relative Clauses in Matlatzinca}

\subsubsection{Maximal Free Relative Clauses in Matlatzinca}

Maximal free relative clauses in Matlatzinca can only be introduced by the $w h$-words for 'who', 'what', and 'where'. One of the forms for the wh-word for 'where' can mean 'how' or 'why' as well, and can introduce maximal free relatives with a manner or reason interpretation. This pattern is summarized in Table 6 .

\begin{tabular}{lllc}
\hline & & & Maximal \\
\hline WHO & & want'ë(wi) & $\checkmark$ \\
& WHO-DU & want'ë-wewí & $\checkmark$ \\
WHAT & WHO-PL & want'ë-hë & $(\checkmark)$ \\
WHICH/WHAT & & nt'ani & $\checkmark$ \\
& WHICH & yant'ë(wi) & $*$ \\
WHEN & WHAT +N & nt'ani + mu N & $*$ \\
WHERE & & yahkhá & $*$ \\
& & poht'i & $\checkmark$ \\
& & poh+pu & $\checkmark$ \\
HOW/WHY & & pu & $\checkmark$ \\
WHY & & pu... + khá V & $\checkmark$ \\
HOW MUCH/MANY & & 'in_khá & $*$ \\
\hline
\end{tabular}

Table 6. Distribution of wh-words across Maximal Free Relative Clauses in Matlatzinca $(\checkmark$ : acceptable and attested in corpus; $(\checkmark)$ acceptable elicited; *: not acceptable; ?: unclear)

Examples are given in the remainder of this section. In accordance with the crosslinguistic pattern, maximal free relative clauses in Matlatzinca can be replaced and paraphrased with definite NPs, with which they share their core semantic properties-referentiality and maximality. The examples in $(39 \mathrm{a}, \mathrm{b})$ exemplify maximal free relative clauses introduced by 'what'. When used to introduce a free relative clause in casual speech, the $w h$-word for 'what' is compacted phonologically to $n t^{\prime} a n=$ and procliticizes to the following word. This is seen in (39a). In contrast, example (39b) reflects a careful pronunciation.

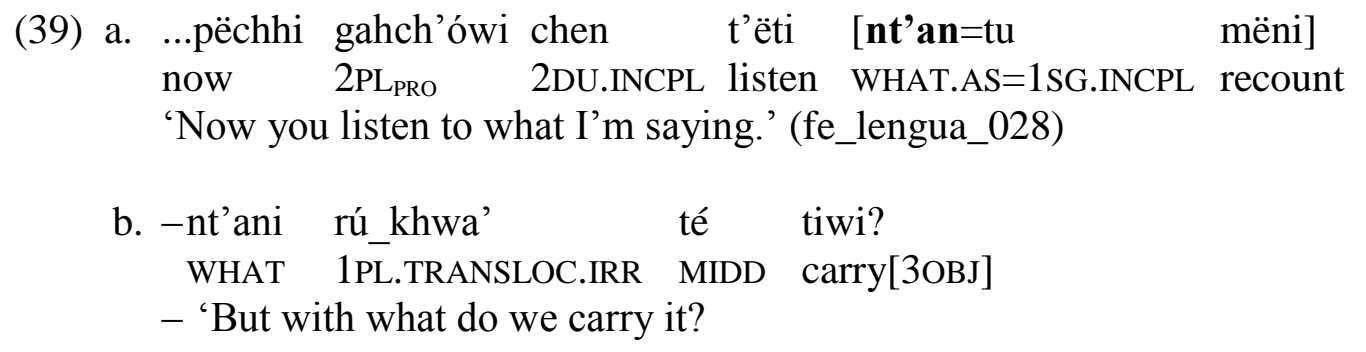




$$
\begin{aligned}
& \text {-ho, [nt'ani ri'a kïxti] ri'a } \\
& \text { yes WHAT 2SG.TRANSLOC.IRR tighten[3OBJ] 2SG.TRANSLOC.IRR take[3OBJ] } \\
& \text { - 'Yes, you carry it with the thing that you tighten it with.' (an_ayates 832.b/833) }
\end{aligned}
$$

Maximal free relatives are semantically close to definite NPs. For instance, the bracketed definite NP in (40) replaces and paraphrases the bracketed maximal free relative clause we saw in (39a). This highlights the close semantic connection between the two morpho-syntactically different constructions: they both point at the speaker's words, i.e., they are both referential.
pëchhi gahch'ówi chen
t'ëti [the be'_mëni]
nOW 2PLPRO
2DU.INCPL listen 1POSS word
'Now you listen to my words.'

Examples (41a,b) show two maximal free relative clauses in brackets, both introduced by the whword for 'who' and both acting as the subject of their matrix clauses. The free relative clause in (41a) refers to the atomic individual who threw gourds, while the one in (41b) refers to the plural individual made of two atomic individuals who threw gourds. In both cases, those individuals are the largest ones - the maximal ones - that have the property of throwing gourds in that context. Crucially, neither maximal free relative clause can be interpreted as an indefinite NP meaning 'one (of those) who threw gourds'.

(41) Context: When there was a festivity, groups of boys would go around the village carrying gourds, and if one of them liked some given girl, he would throw a gourd at her house as a token of his interest in her. In the example below, even though his identity is not known, reference is made to the very boy who threw the gourd (i.e., not just anyone would suffice).

a. If it was one gourd, those at the house would say:
tá'_ma'
kïxi
[want'ëwi tu
'ati]

3SG.TRANSLOC.IRR come.forth WHO 3.CPL throw[3OBJ]

'The one who threw it may come forth.' (ar_ofrenda_494)

b. If it were two gourds, they would say:
[want'ë-wewí ga
tu 'ati-wewí]
tá'_kwá'
kïxi
WHO-DU
PRTCL 3.CPL throw[3OBJ]-DU 3DU.TRANSLOC.IRR come.forth

'The two ones who threw them may come forth.' (ar_ofrenda_496)

Examples of maximal free relative clauses introduced by 'where' are given in (42) and (43). The maximal free relative clause in (42) functions as the focus phrase in a pseudocleft. ${ }^{19}$ An example of $p u$ introducing a manner maximal free relative clause is given in (43). Note the co-occurrence of the manner/reason adverbial khá. Due to the co-occurrence of $p u$ and khá to express manner or reason, speakers have phonologically associated these two words, thus giving rise to the manner/reason conjunction $p u+k h a ́$, which is not a $w h$-word and therefore does not introduce a

\footnotetext{
${ }^{19}$ Note that the adverbial $p u$ 'there' is also found in the verbal complex of the relative clause that encodes the background in the cleft. This adverbial works as a resumptive pronoun, suggesting that the example functions as a correlative: 'where the dead people lie is there we adorn with flowers too'. We thank Ivano Caponigro for this observation.
} 
free relative clause. For instance, the bracketed string in (44) is a causal clausal adjunct, not a free relative clause. If it were a free relative clause, its expected meaning would be something like 'He stayed for the same reason that his father was alone'.

(42) $\left[\mathbf{p u}_{i}\right.$ ro nás baari ne 'anima $]$ WHERE 3PL.INCPL BELOW lie PL dead

mu ga khwén $\mathrm{pu}_{i}$ té hë_tëni

also COP 1PL.EXCL.INCPL THERE MIDD lay.flowers

'Where the dead people lie down is also where we lay flowers.' (ar_ofrenda 381)

(43) ah me kuh thé [pu tu khá 'esti n t'opi]

! just 3SG.INCPL SS.see WHERE3.CPL MANN/REASN grab CLF plough

'Ah! He was just watching (the way) how he grabbed the plough.' (te_vida1_226)

(44) [pu_khá nirawi we tú ni papa] $\mathrm{ku}$ chhori

MANN/REASN be.alone CLF.HUM dead 3POSS dad 3SG.INCPL stay

'Because his late father was alone, he stayed.' (te_vida1_062)

\subsubsection{Existential Free Relative Clauses in Matlatzinca}

Free relative clauses that occur as clausal complements of existential constructions appear to use the same $w h$-words that we find in maximal free relative clauses (although it has been impossible to come up with a felicitous example for manner). This pattern is summarized in Table 7.

\begin{tabular}{|c|c|c|c|}
\hline & & & istential \\
\hline \multirow[t]{3}{*}{ WHO } & & want’ë(wi) & $(\sqrt{ })$ \\
\hline & WHO-DU & want'ë-wewí & $(\sqrt{ })$ \\
\hline & WHO-PL & want'ë-hë & $(\checkmark)$ \\
\hline WHAT & & nt'ani & $\checkmark$ \\
\hline \multirow[t]{2}{*}{ WHICH/WHAT } & WHICH & yant'ë(wi) & $*$ \\
\hline & $\mathrm{WHAT}+\mathrm{N}$ & nt'ani + mu N & * \\
\hline WHEN & & yahkhá & $*$ \\
\hline \multirow[t]{3}{*}{ WHERE } & & poht'i & $(\checkmark)$ \\
\hline & & poh+pu & $(\checkmark)$ \\
\hline & & $\mathrm{pu}$ & $(\checkmark)$ \\
\hline HOW/WHY & & pu... + khá V & $?$ \\
\hline WHY & & 'in_khá & $*$ \\
\hline HOW MUCH/MANY & & mhëxi $(+N)$ & $*$ \\
\hline
\end{tabular}

Table 7. Distribution of wh-words across Existential Free Relative Clauses in Matlatzinca $(\checkmark$ : acceptable and attested in corpus; $(\checkmark)$ acceptable elicited; *: not acceptable; ?: unclear)

Examples of existential free relative clauses are given in (45). The predicate in existential free relatives must be inflected in the irrealis. This type of construction provides an indefinite description, as evidenced by the fact that the clause can be replaced with an indefinite NP, as in (46), which would have equivalent semantics to $(45 \mathrm{~b}, \mathrm{c})$. 
(45)
a. xa' to' pënti [want'ë=tá'_tu t'ent'an-ki]
NEG 1SG.CPL find WHO.AS=3.CPL.IRR help-1SG.OBJ
'I can't find anyone who may help me.'

b. pero pe... ga tët'i man (té) horí [t'an=tá'_tu si] but just PRTCL DEM ${ }_{\text {PRO }}$ 3SG.AMBU MIDD look.for WHAT.AS=3CPL.IRR ingest 'But he was just going along in search of something to eat.' (au_cueva_074)

c. $x a$ ' 'i me' chamba o [poh+pu ri_'íh be't'ani]

NEG 2SG.INCPL have job or WHERE+WHERE 2SG.INCPL.IRR work

'You don't have a job or a place to work.' (dinero_289)

(46) a. pero mahme man horí n ts'omhewi para tá'tu si but just 3SG.AMBU look.for CLF bread PURP 3CPL.IRR eat 'But he was just going along in search of (some) bread to eat.'

b. kach'i xa 'i me' t'ani o na n maani pu ri_'íh be't'ani 2SG $S_{P R O}$ NEG 2SG.INCPL have job or INDF.SG CLF house WHERE 2SG.INCPL.IRR work 'You don't have a job or a house where you can work.'

\subsubsection{Free-Choice Free Relative Clauses in Matlatzinca}

We have seen that maximal and existential free relative clauses in Matlatzinca can only be found with wh-words for 'who', 'what' and 'where'. The same restriction applies to free-choice free relatives, with the caveat that some speakers allegedly also allow for 'how much'. The $w h$-words in question, listed in Table 8, are modified by meya and meyoh; the former of which is used with arguments, and the latter with adjuncts.

\begin{tabular}{|c|c|c|c|}
\hline & As interrogative & As free choice & Semantics \\
\hline WHO & want'ë(wi) & *meya+want'ë(wi) & \\
\hline WHICH & yant"ë(wi) & me (ya)+yant'ë(wi) & HUM \\
\hline WHAT & nt'ani & meya+nt'ani & INAN \\
\hline $\begin{array}{l}\text { WHERE } \\
\text { HOW MUCH }\end{array}$ & $\begin{array}{l}\text { poht'i/poh+pu } \\
\text { mhëxi }\end{array}$ & $\begin{array}{l}\text { meyoh+ poht'i/poh+pu } \\
\text { meyoh+mhëxi }\end{array}$ & $\begin{array}{l}\text { LOC } \\
\text { QUANTITY }\end{array}$ \\
\hline
\end{tabular}

As shown in Table 6, the 'who' $w h$-word cannot be used in a free-choice relative clause. Instead, to refer to a human referent Matlatzinca speakers use the 'which' wh-word, as shown in (47). But this $w h$-word can also be used as a free-choice determiner with inanimate nouns, as shown in (48).

(47) rúh $\quad \mathrm{p}=$ 'ini $\quad[$ me(ya)+yant'ëwi rúh pëti]

1.CPL.IRR THERE=say FREE.CHOICE+WHICH.ONE 1.CPL.IRR find

'I'm going to tell whoever I may find there.' 
(48) me(ya)+yant'ëwi ni xú we rawí?

FREE.CHOICE+ WHICH 3POSS name CLF.HUM one.HUM

'Any name whatsoever?' (Said as an equivalent of 'Any name would do?')

(Lit. 'Whatever its name of someone?') (ar_ofrenda_211.b)

Other examples of free-choice free relative clauses are given in (49). All our examples of freechoice free relative clauses come from elicitation and all are possible, except for the one involving 'how much' in (49c), which is judged to not be as natural as the other ones.
a. ri pári [meya+nt'ani tuh nawí]!
2.CPL.IRR give.to.3[3OBJ] FREE.CHOICE+WHAT 3.CPL.IRR want
'Give her whatever she wants!'
b. rúh $\quad \mathrm{p}=$ hori $\quad$ meyoh $+\mathbf{p o h t} \mathbf{i} / \mathbf{p o h}+\mathbf{p u}$ tu=s chhori]
1.CPL.IRR THERE=look.for[3OBJ] FREE.CHOICE+WHERE 3.CPL.IRR=UP be.located
'I'm going to look for it wherever it is.'
c.? rú si [meyoh+mhëxi 'íh nawí rú
1.CPL.IRR eat FREE.CHOICE+HOW.MUCH 2SG.INCPL want 1.CPL.IRR eat
'I'll eat however much you'd like me to eat.'

The only examples attested in our corpus with the semantics of free-choice involve manner clauses that are not introduced by a $w h$-word. Such examples include the adjunct free-choice element meyoh, as shown in (50).

(50) $\left[\right.$ meyo $^{\mathbf{h}}$ rú (khá) kha $]$ ka rúh yë

FREE.CHOICE 1.CPL.IRR MANN do PRTCL 1.CPL.IRR do[3OBJ]

'No matter how I'd have to do, I'll do it.' (te_vida1_253)

\subsubsection{Conclusions}

As we have seen in this section, free relative clauses are mainly found with 'who', 'what', and 'where'. Table 9 provides a summary of our findings.

\begin{tabular}{lllccc}
\hline & & Maximal & Existential & Free choice \\
\hline WHO & & want'ë(wi) & $\checkmark$ & $(\checkmark)$ & $*$ \\
& WHO-DU & want'ë-wewí & $\checkmark$ & $(\checkmark)$ & $*$ \\
WHAT & WHO-PL & want'ë-hë & $(\checkmark)$ & $(\checkmark)$ & $*$ \\
WHICH/WHAT & & nt'ani & $\checkmark$ & $\checkmark$ & $(\checkmark)($ meya +$)$ \\
& WHICH & yant'ë(wi) & $*$ & $*$ & $(\checkmark)($ meya +$)$ \\
WHEN & WHAT +N & nt'ani + mu N & $*$ & $*$ & $*$ \\
WHERE & & yahkhá & $*$ & $*$ & $*$ \\
& & poht'i & $\checkmark$ & $(\checkmark)$ & $(\checkmark)($ meyoh+) \\
& & poh+pu & $\checkmark$ & $(\checkmark)$ & $(\checkmark)($ meyoh+) \\
HOW/WHY & & pu & $\checkmark$ & $(\checkmark)$ & $*$ \\
WHY & & pu... + khá V & $\checkmark$ & $?$ & $*$ \\
HOW MUCH/MANY & 'in_khá & $*$ & $*$ & $*$ \\
\hline
\end{tabular}

Table 9. Distribution of wh-words across Free Relative Clause constructions in Matlatzinca $(\checkmark$ : acceptable and attested in corpus; $(\checkmark)$ acceptable elicited; *: not acceptable; ?: unclear) 


\subsection{Other Types of Headless Relative Clauses in Matlatzinca}

Apart from the free relative clauses we introduced in the previous section, we have identified three additional constructional strategies to produce headless relative clauses in Matlatzinca. Common to all of these types is the characteristic that they can only occur as arguments of their matrix clauses. In $\S 4.2 .1$, we discuss headless relative clauses introduced by a demonstrative, which we treat as light-headed relative clauses. The two remaining types are grouped together in $\S 4.2 .2$; these lack a light head and do not involve $w h$-words.

\subsubsection{Light-Headed Relative Clauses with a Demonstrative}

This common type of headless relative clause in Matlatzinca is a relative clause that has the distal demonstrative $t^{\prime} i$ or $t^{\prime} t t^{\prime} i$ as a pronominal head, i.e., a light head. Following Čitko (2004), we treat this construction as a light-headed relative clause. It involves a relative clause of the relativizer type (and, more rarely, of the asyndetic type). Examples are given in (51).
(51) a.
pero $\mathrm{mu}$
khá
ts'opi $\quad \mathbf{t}^{\prime}$
t'i $\quad[n \quad$ 'íh
but 3SG.INCPL.DEP MANN/REASN be.called DEM PRO CLF.REL 2SG.INCPL SOW
'But what is the one (i.e., the crop) that you sow called?' (fl_plantas_126.b)
b. tu
ch'ari-hë
$\mathbf{t}^{\prime} \mathbf{i}$
$[\mathrm{n}$
ro'
táchi]

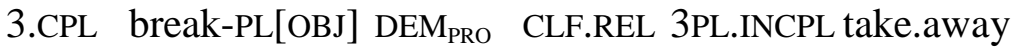
'They broke the ones (i.e., the bells) that they took away.' (ra_campanas_055)

chohti]?

In (51), the referent pointed out by the headless relative clause is readily recoverable from the context. This could lead us to conclude that the structure in (15) involves a null-head. In other words, (51) could be seen as involving a noun that has been elided because it is topical. But while e.g. in Spanish a null-head analysis can be postulated in cases of elision like (52a), Matlatzinca does not allow for this possibility, as shown in (52b). The fact that we cannot elide nouns in Matlatzinca suggests that a null-head analysis of (51) is not desirable. This is the reason why we think that the demonstrative in examples like (51) functions as a light head.

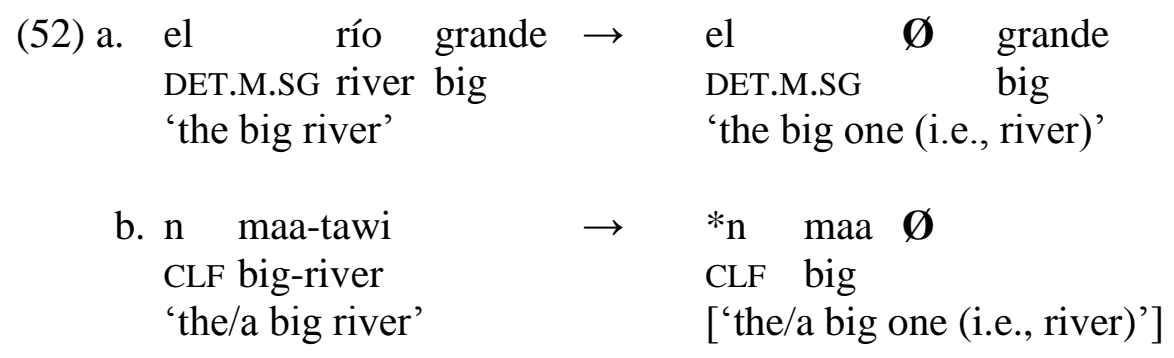

A light-headed relative clause is frequently used to make reference to an entity for which speakers lack a noun; this may be because there is no such noun in Matlatzinca, or because they do not recall the noun in question at the time of speaking. An example is (53).
(53)
$\begin{array}{llllll}\text { mëchí } & \text { na } & \mathrm{n} & \text { t'ani } & \text { khwen } & \text { t'ini... } \\ \text { pierce.IMP } & \text { INDF.SG } & \text { CLF thing } & \text { 1PL.INCL.INCPL } & \text { SS.say }\end{array}$ 
tit'i [n khwa' mëchí para ne ri’áxi pu tá'=ré unido] DEM $_{\text {PRO }}$ REL 1PL.INCL.TRANSLOC pierce P:to PL leather WHERE 3.CPL.IRR=MIDD put.together 'Pierce the thing that we call..., the one we pierce the layers of leather with where they join together.' (fe_lengua_148)

Example (54) is particularly interesting. It is a response to the question, "With which of your children do you still speak Matlatzinca?" The speaker makes reference to two of his sons by identifying them by the place to which they have emigrated.

(54) a. pero ma pëkhi the mhuteti $\dot{\mathrm{t}}_{\mathrm{i}} \underline{\mathbf{i}}_{\mathrm{i}} \quad[\mathrm{ma}$, pa $\mathrm{h}$ México $]$,

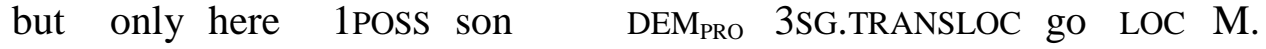

'But only my son here, the one who is in Mexico,' (fe_aserradero_040)

$\begin{array}{lllll}\text { b. 'ix=ta } & \text { tit'i }^{\text {and=PRTCL }} & \text { [ma' } & \text { pa } & \text { Norte }] \\ \text { DEM } & \text { 3SG.TRANSLOC } & \text { go } & \text { US }\end{array}$

'and that one, who is in the U.S.' (fe_aserradero_041)

The light-headed relative clause in (54b) introduces the second son, and it is a clear example of a headless relative clause like examples (51) or (53). But the clause in (54a) occurs right after the noun introducing the first son; in other words, it occurs immediately after the noun with which it shares a referent. With examples like this one, it is difficult to set a clear boundary between a headless and a headed interpretation of the relative clause. To see this more clearly, consider example (55), which shares its general structure with (54a). This sentence could equally receive either the interpretation in (55a), thus instantiating a light-headed relative clause, or the one in (55b), thus instantiating a headed relative clause construction, in which case the demonstrative would now function as a relativizer. In examples from natural discourse, we prefer to interpret cases like (55) as an appositional light-headed relative clause, like the analysis in (55a), which is used to restrict the reference of a noun that is introduced in the immediate previous discourse. But it could equally be the case that utterances like (55), which occur in elicitation, could be interpreted as in (55b) like instances of an emergent headed relative clause construction.

(55) tan kareta tit'i ron t'ini kin guajolotera (cl_hongos_047.b)

a. ta $\mathrm{n}$ kareta ${ }_{\mathrm{i}}, \underline{\text { tit' }}_{\mathrm{i}}$ [ron t'ini ki $\mathrm{n}$ guajolotera

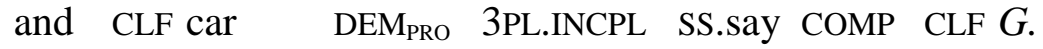

'that car, that one that they say that it's a "Guajolotera",

b. ta $\mathrm{n}$ kareta [tit'i ron t'ini ki $\mathrm{n}$ guajolotera]

and CLF car REL 3PL.INCPL SS.say COMP CLF G.

'that car that they say that it's a "Guajolotera", 


\subsubsection{Headless Relative Clauses Without Light Heads or Wh-words}

There are two other types of headless relative clauses in Matlatzinca that are neither free relative clauses nor do they involve a light head. ${ }^{20}$ They correspond to the headed relative clause types that we described in $\$ 3.2 .1$ and $\$ 3.2 .3$. The first type is introduced by a relativizer, whereas the second one has no complementizer. In terms of usage, like their light-headed counterparts, they can occur as arguments.

Headless relative clauses of the relativizer type. This type of headless relative clause make use of the same relativizer $n$ that introduces the headed relative clauses that we discussed in §3.2.3. This type of headless relative clause is only used with a maximal interpretation (i.e., a definite referent), as illustrated in (56).

(56) a. ga khwen hóhya [n gu khana pax-kwentu...]

PRTCL 1PL.INCL.INCPL forget REL 3SG.INCPL WELL keep-talk

'And we forget about the one who has a good command of the language...' (ra_campanas_130)

b. tá'_tu hë-hë n lucha pëchhi

3.CPL.IRR do-PL CLF fight now

be_hnun-hë ne to bu-muchacho [tu pënt-hë n to ribawi]

poor-PL PL DIM young-boy 3.CPL learn-PL CLF dim spelling.book

'ix [n tu hé-hë mu ra $\mathrm{n}$ letra $]$

and REL 3.CPL see-PL other INDF.SG CLF letter

'May they now fight for it, the poor young boys who learnt their spelling book and those who saw some other letters.' (ra_campanas_120b-122b)

Headless relative clauses of the asyndetic type. Finally, headless relative clauses in Matlatzinca can also be analogous to the syndetic relative clauses that we discussed in \$3.2.1. This means that the equivalent of an English free relative clause such as I had for lunch what you prepared

\footnotetext{
${ }^{20}$ Certain usages of deverbal agent nouns in Matlatzinca could be mistaken for instances of nominalized relative constructions. Such nouns are productively built by the derivational marker be', e.g. t'ani 'work' $\rightarrow$ be' t'ani 'worker'. The primary function of agent nouns is to make reference to certain individuals by profiling them based on their role as agents in certain events, e.g. ne be' té hori \{PL DER MIDD search\} 'the ones who search' (lit. 'the searchers') (ra_campanas 018.b). In this, they have the same function as maximal headless relative clauses. The case is particularly interesting with instances of the construction that involve the stative transitive verb me' 'have' as the main predicate, because this verb can function as an agent noun by conversion (i.e., it has no need of be'), e.g. $n$ me'+реnu \{CLF have+hat\} 'the one having a hat' (lit. 'the hat-haver'). The object of me' 'have' is often a bare incorporated noun, but not always. In our corpus, there are very rare cases where other verbal stems are used as agent nouns via conversion, e.g. ne panti chi'mi \{PL gather chili.sauce\} 'those who gather the chili sauce' (ma_mole325). These nouns can occur in apposition to other nouns or pronouns, and in such cases they are functionally similar to headed relative clauses because they restrict the reference: e.g. ret'ë-hë, ne me' $n$ to chutata baat' $i\left\{3_{\mathrm{PRO}}-\right.$ PL PL have CLF DIM saint there $\}$ 'they who have the saint over there' (an_ofrenda 065). We treat all these cases as NPs. Their true nature as nouns can be seen in apposition. Deverbal nouns require a general classifier. When in apposition, the deverbal noun does not agree with the classifier features of the noun with which it shares its referent: e.g. t'i we towa' a, *we/n me'+ penu \{DEM CLF.HUM child CLF.HUM/CLF have+hat\} 'the child with the hat' (lit. 'the child, the hat-haver'). We would expect agreement in classifier features if the construction was a relative clause.
} 
for me yesterday could literally be rendered in Matlatzinca as 'I had for lunch you prepared for me yesterday'. As a matter of fact, the asyndetic type of headless relative clause is the most common type in Matlatzinca natural discourse. Examples are given in (57). All three examples are interpreted as maximal (i.e., as referring to the maximal individual of a given set). They all occur as the subject of their matrix clause. In (57a), it is the subject of the headless relative clause that is relativized, while it is the object in $(57 \mathrm{~b}, \mathrm{c})$.
(57)a. [me $\mathrm{n}$ to meriu _ _ suBJ $]_{\text {SUBJ }}$ tu táni $\mathrm{n}$ to pari 'ix $\mathrm{n}$ to burro have CLF DIM money 3SG.CPL buy CLF DIM horse or CLF DIM donkey 'The one who has money buys a horse or a donkey.' (Lit. 'Has money buys a horse or a donkey.') (an_ayates_801)

b. ho, kuh pëki [khwén pu=n pantí _oBJ $]_{\text {SUBJ }}$ yes 3SG.CPL be.a.lot 1PL.EXCL.INCPL THERE=LK gather 'Yes, there was a lot of what we used to gather up.' (Lit. '...there was a lot we used to gather up.') (lu_tortillas_087)

c. no tata, cha' phi [gahch'ówi chhan tu hëwi __oвs] $]_{\text {SuBj }}$ no sir NEG be.so 2PLPRO 2PL.AMBU INFL do 'No sir, what you (PL) are doing is not good.' (Lit. '...is not so you (PL) are doing.') (ar_historias_076)

The type of asyndetic clause we observe in (57) is also the default encoding for the background relative clause in pseudoclefts. This is illustrated in (58), which involves a question-answer exchange. In the answer, the speaker produces two asyndetic relatives. The first one is a headless relative clause that introduces a definite referent as a topic. The second one is part of a pseudocleft; in this case, the relative clause further elaborates on the topic. A similar situation is given in (59), where the pseudocleft has no overt copula.

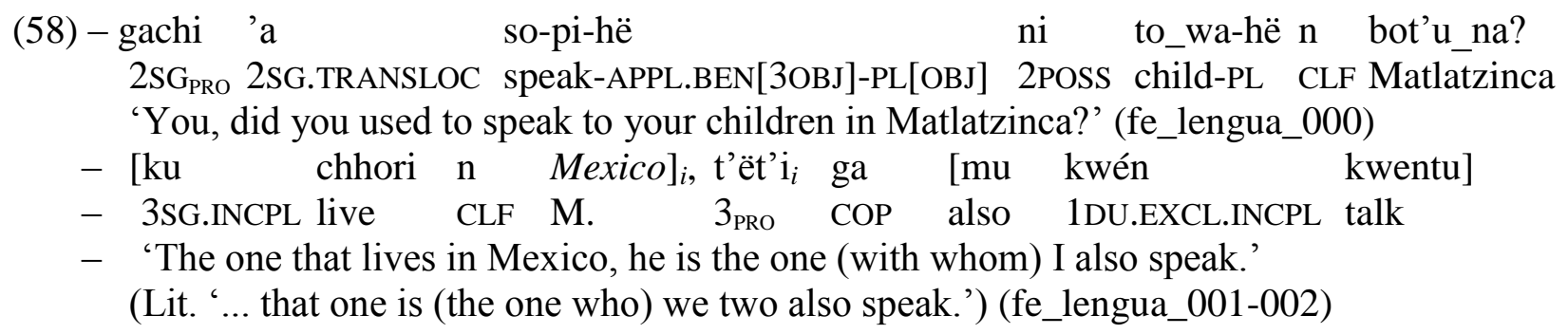

(59) $\mathrm{n}$ to sebara $_{i}, \mathrm{t}^{\prime} \ddot{\mathrm{e}} \mathrm{t}^{\prime} \mathrm{i}_{i}$ _ [ro_man táni]

CLF DIM barley $3_{\text {PRO }}$ COP 3PL.AMBU buy

'The barley, that is the one that they buy.' (rn_pulque_192)

We maintain that the clauses in the pseudoclefts in (58)-(59) are relative clauses. Such an analysis makes Matlatzinca syntax coherent with what is expected of clefts from a crosslinguistic perspective. In their typology of clefts, Drubig and Schaffer (2001) conclude that the only existing agreement about clefts is that the subordinate structure within them must be analyzed as a relative clause. This view stems from Schachter (1973) and is continued in the pragmatic- 
syntactic approach of Lambrecht (2001). But most crucially, we have seen in $\$ 3.2 .1$ that asyndetic relative clauses exist and are common in Matlatzinca, so there is no reason that one should doubt the status of the structure in the clefts in (58)-(59) as a relative clause. What remains to be decided is what type of relative clause they are. In other words, are they true headless relative clauses, functionally equivalent to a free relative clause in English clefts such as It's John who left? Or do they instantiate some other type of relative clause that cannot function as a headless relative clause elsewhere, as the relative clause that left in an English cleft like It's John that left? In this respect, we propose that the asyndetic relative clauses in pseudoclefts in Matlatzinca are indeed true headless relative clauses. We base this claim on the fact that the most exemplary instance of a headless relative clause in this language is, as we have shown in (57), precisely the asyndetic relative clause type. $^{21}$

Finally, asyndetic headless relative clauses are also the default and most natural headless relative clauses to be interpreted as existential (i.e., like indefinites). This reading is always and only licensed when an asyndetic headless relative clause occurs as the complement of the existential predicate $w a{ }^{22}$ No other type of headless relative clause (free relative or light-headed) can occur as complement of this predicate. Examples of this construction are given in (60).

(60)a. cha' wa' [mu tu tent'án-ki]

NEG EXIST 3.INCPL.DEP INFL help-1OBJ

'I don't have anybody to help me.'

(Lit. 'There isn't (who) helps me.') (ma_ofrenda_334)

b. cha' wa' [khwén té pawí]

NEG EXIST 1PL.EXCL.INCPL MIDD fight

'I don't fight with anybody.' (Lit. 'There isn’t (who) we fight each other.') (cl_hongos_125)

c. $o$ wa' [ma' hih-k'i]

or EXIST 3SG.TRANSLOC teach-2SG.OBJ

'Or someone taught you.' (Lit. 'Or there is (who) taught you.') (an_ayates_686.b)

${ }^{21}$ In contrast, Matlatzinca also has the equivalent of English that relative clauses in clefts. For these, the language uses the relativization strategy involving the complementizer $k i$ presented in $\$ 3.2 .2$, which cannot be used to create a headless relative clause (in the sense used in this book). An example of a cleft where this occurs is shown in (i):

(i) $y$ despues $p=r e n \quad$ gi $n \quad x i$ xi $\left[\begin{array}{llll}k i & r u ́ & y \ddot{e}-h \ddot{e}]\end{array}\right.$ and later.on there $=3_{\mathrm{PRO}}$ COP CLF grass COMP 1.CPL.IRR do-PL[SUBJ]

'And later on there it is, the grass that we're going to deal with.' (ar_vida_49)

We are grateful to Ivano Caponigro for raising this point, which needed clarification, with us.

${ }^{22}$ Speakers have reanalyzed the verb $w a$ ' 'exist' as an indefinite pronoun:

(i) $x i$ ' 'an 'ini wa'

NEG 2SG.AMBU AS.say someone

'Don't go and tell anybody.' (au_lumbre_151)

The wh-word want'ë(wi) 'who', which can be used as an indefinite pronoun, results from the lexicalization of the string in (ii):

(ii) $w a-n-t ' \ddot{e}+w i$

EXIST-LK-3 $3_{\mathrm{PRO}}$

's/he exists' $\rightarrow$ 'someone' $\rightarrow$ 'who' 


\section{Conclusions}

We have shown in this chapter that Matlatzinca has a relatively rich array of encoding possibilities for headless relative clauses. The array includes three different main types: free relative clauses, light-headed relative clauses, and headless relative clauses involving some type of complementizer. By way of summary, in Table 10 we present in detail the different types of possibilities and their distribution according to the semantic type of the relativization relation.

\begin{tabular}{|c|c|c|c|c|c|c|c|}
\hline & HUM & -HUM & LOC & TIME & MANNER & REASON $^{23}$ & QUANT. \\
\hline \multicolumn{8}{|l|}{ Free relative clauses } \\
\hline Maximal (§4.1.1) & $\checkmark$ & $\checkmark$ & $\checkmark$ & $*$ & $\checkmark$ & $*$ & $*$ \\
\hline Existential (§4.1.2) & $(\checkmark)$ & $(\checkmark)$ & $(\checkmark)$ & $*$ & $?$ & $*$ & $*$ \\
\hline Free-choice $(\$ 4.1 .3)$ & $(\sqrt{ })$ & $(\checkmark)$ & $(\checkmark)$ & * & $\dot{\checkmark}^{24}$ & $*$ & $(?)$ \\
\hline \multicolumn{8}{|l|}{ Light-headed } \\
\hline With determiner (§4.2.1.a) & $\checkmark$ & $\checkmark$ & $*$ & $*$ & $*$ & $*$ & $*$ \\
\hline \multicolumn{8}{|l|}{ Other types } \\
\hline With a relativizer $(\$ 4.2 .2 . \mathrm{a})$ & $\checkmark$ & $(\checkmark)$ & $*$ & $*$ & $*$ & $*$ & $*$ \\
\hline Asyndetic $(\S 4.2 .2 . c)$ & $\checkmark$ & $\checkmark$ & $*$ & $*$ & $*$ & $*$ & $*$ \\
\hline
\end{tabular}

Table 10. Headless relative clause types in Matlatzinca and their semantic scope

$(\checkmark$ : acceptable and attested in corpus; $(\checkmark)$ acceptable elicited; *: not acceptable; ?: unclear)

Reference to a maximal individual can be encoded by means of four different kinds of relative clauses. Speakers can use either a maximal free relative clause, a light-headed relative clause, a headless relative clause of the relativizer type, or an asyndetic headless relative clause. For instance, the examples in (61) instantiate a light-headed and an asyndetic headless relative clause, respectively, while making reference to the same maximal plural individual. Both clauses have the same syntactic function as arguments of the same predicate, and they occur very close to each other in the discourse. We find this range of encoding options remarkable. It makes the analysis of the syntax of natural Matlatzinca discourse particularly challenging, and deserves further attention in future studies.

(61)a. 'ix tit'i $\quad[$ ron kïwi n campana $] \ldots$ and DEM $_{\mathrm{PRO}}$ 3PL.CPL ring CLF bell

'and those that ring the bell...' (an_mole_017)

b. xi [ron kïwi n campana $]$...

and.also 3PL.CPL ring CLF bell

'and those that ring the bell...' (an_mole_022)

The present overview of the headless relative clauses we find in Matlatzinca has been made possible by the study of a reasonable-sized corpus of natural spoken data that is a preliminary outcome of ongoing language documentation activities. An earlier exercise using elicitation from translations from Spanish rendered a few poorly structured free relative clauses and no trace of asyndetic relative clauses, either of the headed or the headless subtypes. If we consider the fact that free relative clauses exist and that asyndetic relative clauses are the most common

${ }^{23}$ As illustrated in (50), free-choice manner clauses are not introduced by $w h$-words.

${ }^{24}$ Like in example (50), only in manner clauses that are not introduced by wh-words. 
relativization strategy in Matlatzinca natural discourse, their failure to occur in elicitation is noteworthy and reveals the great extent to which linguistic data can differ depending upon the method of data extraction that we use. Our conclusions about the linguistic system of Matlatzinca would have been biased and poorly understood had we used our elicitation data alone. This methodological caveat is of particular importance for typological research on minority languages.

\section{Acknowledgments}

This chapter has benefitted from three research projects: the 2017-2018 UC-Mexus-CONACyT project "Headless relative clauses in Mesoamerican languages"; the 2017-2019 ELDP-Major Documentation Project "Documentation of Matlatzinca: An Oto-Manguean language"; and the 2015-2017 CNRS-CIESAS PICS "Mésoamérique et la syntaxe de la proposition relative". We are greatly indebted to the editors of this volume and to the anonymous referees for their help and comments. Special thanks to Ivano Caponigro for his insightful comments and suggestions as to how to improve the argumentation. We are equally grateful to all participants of the Headless Relative Clauses Workshops at CIESAS in San Cristobal de las Casas during 2017 and 2018 for both the company and the depth and intellectual beauty of the exchanges. We heartily thank September Cowley for proofreading the English so efficiently and Christine Bartels for her professional editing. All errors and deficiencies remain our own responsibility.

\section{References}

Bartholomew, D. (1966). Observations about Matlatzinca grammar based on informant work done in May, 1966. MS.

Brown, C. H. (2015). Comparative Otomanguean: A review and evaluation. Ms., Northern Illinois University.

Campbell, E. W. (2017). Otomanguean historical linguistics: past, present and prospects for the future. Language \& Linguistics Compass 11: doi.org/10.1111/lnc3.12240.

Caponigro, I., Introducing Headless Relative Clauses and the findings from Mesoamerican languages. This volume

Carranza Martínez, L. (2012). Flexión verbal del matlatzinca: Marcación de persona-número y de tiempo-aspecto-modo. Unpublished MA dissertation at the Metropolitan Autonomous University of Mexico.

Cazes, D. (1971). La lengua Maclasinca de Nsampaanchu, San Francisco Oxtotilpan. Journal de la Société des Américanistes, 60, 191-232.

Čitko, B. (2004). On headed, headless, and light-headed relatives. Natural Language and Linguistic Theory, 22, 95-126.

Drubig, H.B, \& Schaffar, W. (2001). Focus constructions. In M. Haspelmath, E. Koenig, \& W. Oesterreicher (Eds.), Language Typology and Language Universals, 1079-1104. Berlin: Mouton de Gruyter.

Escalante, R \& Hernández, M. (1999). Matlatzinca de San Francisco Oxtotilpan, Estado de México. [Archivo de lenguas indígenas de México 23]. Mexico City: El Colegio de Mexico.

Gómez González, N. B. (2015). La expresión de la definitud en el matlatzinca de San Francisco Oxtotilpan, E. M. Unpublished BA thesis at the National School for Anthropology and History, Mexico.

Lambrecht, K. (2001). A framework for the analysis of cleft constructions. Linguistics, 39(3): 463-516. 
Palancar, E. L. \& Leonardo Carranza Martínez. (2017). Inflectional class interaction in Matlatzinca. Paper read at the Morphological Eye, University of Surrey, 8-9, September.

Pascacio Montijo, E. T. (2006). Fonología de la lengua matlatzinca. Unpublished MA thesis at the National School for Anthropology and History, Mexico.

Pascacio Montijo, E. T. (2017). El vocabulario castellano-matlatzinca (1557): descripción filológica, morfológica y fonológica. Unpublished $\mathrm{PhD}$ Thesis at National Autonomous University of Mexico.

Pérez, N. (2007). Synchronic and diachronic Matlatzinkan phonology. Unpublished PhD thesis at the University of Michigan.

Schachter, P. (1973). Focus and relativization. Language, 49(1), 20-46.

Soustelle, J. (1937). La famille Otomi-Pame du Mexique Central. Paris: Institut d'ethnologie. 